\title{
In Vitro Rooting and Greenhouse Acclimatization of Lachenalia Shoots
}

\author{
James R. Ault ${ }^{1}$ \\ Department of Horticulture, Longwood Gardens, P.O. Box 501, Kennett \\ Square, PA 19348
}

Additional index words. bulb, cape cowslip, micropropagation, tissue culture

\begin{abstract}
Shoot formation was obtained from Lachenalia arbuthnotiae W.F. Barker, L. bulbifera (Cyrillo) Engl., and L. purpureo-coerulea Jacq. leaf tissue explants cultured on

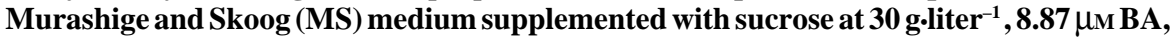
and $0.44 \mu_{\mathrm{M}}$ K-NAA. Shoots of all three species rooted on subculture to MS medium supplemented with $0.0,4.14$, or 8.29 $\mu_{M}$ K-IBA or $0.0,4.46$, or 8.92 $\mu_{M}$ K-NAA. Maximum percent rooting was $\approx 81 \%$ from treatment with $4.14 \mu_{\mathrm{M}} \mathrm{K}$-IBA for $L$. arbuthnotiae and with $8.29 \mu \mathrm{m}$ K-IBA for $L$. purpureo-coerulea; it was $59 \%$ from treatment with $8.92 \mu \mathrm{m}$ K-NAA for $L$. bulbifera. Rooted and nonrooted shoots were acclimatized in a greenhouse. Survival of rooted plants was $93 \%$ for $L$. arbuthnotiae, $95 \%$ for $L$. bulbifera, and $94 \%$ for L. purpureo-coerulea. Survival of nonrooted shoots was $71 \%$ for $L$. arbuthnotiae and $91 \%$ for $L$. bulbifera. Chemical names used: 6-benzyladenine (BA); potassium salt of indole-3butyric acid (K-IBA); potassium salt of 1-naphthaleneacetic acid (K-NAA).
\end{abstract}

Lachenalia is a genus of bulbous geophytes endemic to South Africa. The genus includes many species with excellent horticultural merit (Duncan, 1988). Lachenalia species can be propagated from seed and bulb cuttings, and some from leaf cuttings (Duncan, 1988) and through tissue culture (Klesser and Nel, 1976; Nel, 1983; Niederwieser and Vcelar, 1990). The effects of explant-tissue age and orientation, sucrose, BA, and NAA on adventitious bud formation from leaf tissue have been investigated (Niederwieser and van Staden, 1992; van Staden and Drewes, 1994; van Rensburg and Vcelar, 1989). Klesser and Nel (1976) and Nel (1983) have published limited information on the in vitro rooting and greenhouse acclimatization of Lachenalia tissue-culture shoots. Neither report includes survival rates of rooted shoots after acclimatization or a protocol for greenhouse acclimatization. Therefore, I report on the effect of IBA and NAA on the in vitro rooting of three Lachenalia species and on their greenhouse acclimatization and survival, none of which, to my knowledge, have been reported to be propagated by tissue culture.

\section{Materials and Methods}

Three species were investigated: $L$. arbuthnotiae, $L$. bulbifera (formerly $L$. pendula), and L. purpureo-coerulea. The tissue culture technique used for shoot regeneration was similar to that previously reported for Lachenalia (Nel, 1983; Niederwieser and

Received for publication $21 \mathrm{Feb} .1995$. Accepted for publication 18 July 1995. I gratefully acknowledge the technical assistance of Barbara Skye, graduate student. The cost of publishing this paper was defrayed in part by the payment of page charges. Under postal regulations, this paper therefore must be hereby marked advertisement solely to indicate this fact.

${ }^{1}$ Current address: Chicago Botanic Garden, 1000 Lake Cook Rd., P.O. Box 400, Glencoe, IL 60022.
Vcelar, 1990). Leaves were cut off just above the bulbs from greenhouse-grown plants near full floral anthesis. Leaves were rinsed in running tap water for $5 \mathrm{~min}$, surface-disinfected in a solution of $1.0 \%$ sodium hypochlorite and $0.1 \%$ Tween 20 for $12 \mathrm{~min}$, then rinsed twice in sterile distilled water $5 \mathrm{~min}$ each time. Individual leaf explants, each $5 \times 10 \mathrm{~mm}$, were placed horizontally, abaxial side down, in $25 \times$ $150-\mathrm{mm}$ culture tubes containing $10 \mathrm{ml}$ of medium, which consisted of MS (Murashige and Skoog, 1962) basal salts and vitamins, sucrose at $30 \mathrm{~g} \cdot$ liter $^{-1}, 8.87 \mu \mathrm{M} \mathrm{BA}$, and 0.44 $\mu \mathrm{M}$ K-NAA. Medium $\mathrm{pH}$ was adjusted to 5.7 before adding Sigma A 1296 agar (Sigma Chemical Co., St. Louis) at $6.0 \mathrm{~g} \cdot \mathrm{liter}^{-1}$. Culture tubes were sealed with polypropylene caps and autoclaved at $121 \mathrm{C}$ for $15 \mathrm{~min}$.

After explant placement, culture tubes were sealed with parafilm, then placed upright in 40-tube racks in an incubator (model 818; Precision Scientific, Chicago). Cultures were maintained at $22 \mathrm{C}$ and given a 16 -h photoperiod with a photosynthetic photon flux of 30 to $44 \mu \mathrm{mol} \cdot \mathrm{m}^{-2} \cdot \mathrm{s}^{-1}$ provided by two $40-\mathrm{W}$ broadspectrum fluorescent lamps (Verilux, Greenwich, Conn.). Photosynthetic photon flux was measured with a quantum sensor (model LI190SA; LI-COR, Lincoln, Neb.). Shoots were subcultured every 5 to 10 weeks to the same medium to obtain sufficient shoots for the rooting study.

For rooting, nonrooted shoots, 2 to $7 \mathrm{~cm}$ tall, of each species were cultured individually on MS medium supplemented with $30 \mathrm{~g}$ sucrose/liter and $0.0,4.14$, or $8.29 \mu \mathrm{M} \mathrm{K-IBA,} \mathrm{or}$ $0.0,4.46$, or $8.92 \mu \mathrm{M}$ K-NAA. Percent rooting was recorded after 9 to 10 weeks. Shoots with at least one root $\geq 1.0 \mathrm{~cm}$ long were considered rooted. Rooted shoots of $L$. purpureo-coerulea and rooted and nonrooted shoots of $L$. arbuthnotiae and L. bulbifera then were removed from tissue culture for acclimatization in the greenhouse. Shoots were planted in 72cell plug trays, each cell containing $\approx 40 \mathrm{~cm}^{3}$ medium of 3 sand : 1 peatmoss (v/v). Trays were covered with clear plastic domes, then placed under $50 \%$ shadecloth in the greenhouse. The greenhouse averaged $18.6 \mathrm{C}$ with a maximum of $25.0 \mathrm{C}$ and a minimum of $5.6 \mathrm{C}$ during the acclimatization period. The plastic domes were propped up $\approx 3 \mathrm{~cm}$ on one side after 2 weeks and completely removed after 3 weeks. The shoots received $\approx 9.5 \mathrm{~h}$ of natural photoperiod. Shoot survival was recorded 8 weeks after the shoots were removed from tissue culture.

For shoot initiation, 80 leaf explants were used for L. bulbifera and 120 each for the other two species. For the rooting study, individual shoots of each species were removed from the proliferation medium and were assigned randomly to each of the five rooting treatments. The number of shoot explants used for each rooting treatment was 30 for L. arbuthnotiae and 40 for L. bulbifera and L. purpureocoerulea. The rooting study was conducted once. Rooting percentage was analyzed with the $\mathrm{G}$ statistic, comparing the individual auxin treatments to the control for each species.

\section{Results}

Shoots were evident on the leaf explants within 3 weeks for $L$. bulbifera and $L$. arbuthnotiae and within 5 weeks for $L$. purpureo-coerulea after culture initiation. Shoots subcultured to fresh proliferation medium readily formed additional shoots. Lachenalia arbuthnotiae and L. bulbifera produced callus from most subcultured shoots, whereas $L$. purpureo-coerulea rarely produced callus. Callus was excised and discarded each subculture. Explants on proliferation medium did not produce roots.

Shoots of all three species rooted on all rooting media. Three of the four auxin treatments significantly increased rooting percentage for L. arbuthnotiae and L. bulbifera compared to the nontreated cuttings (Table 1). Conversely, the auxin treatments had no effect or significantly decreased rooting percentage for $L$. purpureo-coerulea compared to the control. Maximum percent rooting was $\approx 81 \%$ from treatment with $4.14 \mu \mathrm{M} \mathrm{K}-\mathrm{IBA}$ for $L$. arbuthnotiae and with $8.29 \mu \mathrm{M} \mathrm{K}$-IBA for $L$. purpureo-coerulea; it was $59 \%$ from treatment with $8.92 \mu \mathrm{M}$ K-NAA for L. bulbifera. Klesser and Nel (1976) reported 65\% rooting for one Lachenalia hybrid cultured on medium containing $5.37 \mu \mathrm{M}$ NAA; subsequently, $\mathrm{Nel}(1983)$ reported that $9.80 \mu \mathrm{M}$ IBA resulted in better rooting than treatment with NAA, but did not include any data.

Lachenalia species appear to vary in shoot rooting response according to the type and concentration of auxin used to stimulate rooting. Niederwieser and van Staden (1992) similarly reported that Lachenalia hybrids vary in their optimal cytokinin requirements for bud stimulation. Therefore, for micropropagation of each Lachenalia genotype, it may be necessary to test several concentrations of various growth regulators for optimal shoot production and rooting.

For this study, survival of rooted shoots 
Table 1. Auxin effects on the rooting percentage of Lachenalia arbuthnotiae, L. bulbifera, and L. purpureocoerulea after 9 to 10 weeks of culture on rooting medium.

\begin{tabular}{|c|c|c|c|c|}
\hline & & \multicolumn{3}{|c|}{ Rooting $(\%)^{\mathrm{z}}$} \\
\hline \multicolumn{2}{|c|}{ Auxin $(\mu \mathrm{M})$} & \multicolumn{3}{|c|}{ Species } \\
\hline K-IBA & K-NAA & L. arbuthnotiae & L. bulbifera & L. purpureo-coerulea \\
\hline 0.0 & 0.0 & 43.3 & 22.0 & 76.2 \\
\hline 4.14 & 0.0 & $81.3^{* *}$ & 36.4 & 57.4 \\
\hline 8.29 & 0.0 & $68.6^{*}$ & $43.9^{*}$ & 81.3 \\
\hline 0.0 & 4.46 & $71.4^{*}$ & $52.5^{* *}$ & $53.5^{*}$ \\
\hline 0.0 & 8.92 & 60.6 & $58.8^{* *}$ & $54.3^{*}$ \\
\hline
\end{tabular}

${ }^{\mathrm{z}}$ Significance within each species based on the comparison of individual auxin treatments with the control (no hormone) using the $\mathrm{G}$ statistic.

*,** Significant at $P \leq 0.05$ or 0.01 , respectively.

after removal from tissue culture was $93 \%$ (96 of 103) for L. arbuthnotiae, $95 \%$ (170 of 179) for L. bulbifera, and $94 \%$ (123 of 131) for $L$. purpureo-coerulea. Survival of nonrooted shoots was $71 \%$ (20 of 28) for L. arbuthnotiae and $91 \%$ (170 of 186) for L. bulbifera. These results compare favorably to Klesser and Nel's (1976) finding of 50\% survival in a greenhouse for nonrooted shoots of a Lachenalia hybrid. Therefore, the labor and cost of rooting shoots in vitro might be eliminated, and instead, nonrooted shoots might be established directly in a greenhouse.

\section{Literature Cited}

Duncan, G.D. 1988. The Lachenalia handbook. Ann. Kirstenbosch Botanic Gardens 17:1-71.
Klesser, P.J. and D.D. Nel. 1976. Virus diseases and tissue culture of some South African bulbs. Acta Hort. 59:71-76.

Murashige, T. and F. Skoog. 1962. A revised medium for rapid growth and bioassays with tobacco tissue cultures. Physiol. Plant. 15:473479.

Nel, D.D. 1983. Rapid propagation of Lachenalia hybrids in vitro. S. Afr. J. Bot. 2(3):245-246.

Niederwieser, J.G. and B.M. Vcelar. 1990. Regeneration of Lachenalia species from leaf explants. HortScience 25:684-687.

Niederwieser, J.G. and J. van Staden. 1992. Interaction between benzyladenine, naphthaleneacetic acid and tissue age on adventitious bud formation on leaf sections of Lachenalia hybrids. S. Afr. J. Bot. 58(1):13-16.

Van Rensburg, J.G.J. and B.M. Vcelar. 1989. The effect of sucrose concentration on the initiation and growth of adventitious buds from leaf tissue of Lachenalia. S. Afr. J. Bot. 55(1):117-121.

Van Staden, J. and F.E. Drewes. 1994. The effect of benzyladenine and its glucosides on adventitious bud formation on Lachenalia leaf sections. S. Afr. J. Bot. 60(3):191-192. 